\title{
The emblematic "Captaincookia" in New Caledonia (Rubiaceae), a divergent Ixora species showing adaptive variability from humid to sclerophyll forests
}

\author{
Arnaud Mouly ${ }^{1, *}$, Thierry Deroin ${ }^{2}$, Daniel Verhaegen ${ }^{3}$ \& Jérôme Munzinger ${ }^{4,5}$
}

\author{
${ }^{1}$ Université Bourgogne Franche-Comté - CNRS UMR 6249 Chrono-environnement, ESPE de Besançon, 16 Route de Gray, FR-25030 \\ Besançon Cedex, France. \\ ${ }^{2}$ Muséum national d'Histoire naturelle, Département Systématique et Évolution, UMR CNRS 7205, ISYEB, CNRS, MNHN, UPMC \& \\ EPHE, case postale 39, 57 rue Cuvier, FR-75231 Paris Cedex 5, France. \\ ${ }^{3}$ Cirad, Bios-UMR Agap "Genetic diversity and breeding of forest trees", TA A-108/C, Baillarguet, FR-34398 Montpellier Cedex 5, France \\ ${ }^{4}$ Institut de Recherche pour le Développement, UMR AMAP, Laboratoire de Botanique et d'Écologie Appliquées, Herbarium NOU, BP A5, \\ FR-98848 Nouméa Cedex, New Caledonia, France \\ ${ }^{5}$ Current address: IRD, UMR AMAP, FR-34000 Montpellier, France \\ *Author for correspondence: arnaud.mouly@univ-fcomte.fr
}

\begin{abstract}
Background and aims - Ixora margaretae, endemic to New Caledonia, is a flagship for the archipelago's sclerophyllous forests. Recently, three populations of an Ixora resembling I. margaretae were found in humid forest.

Methods - Genetic studies using SSR markers and morpho-anatomical studies of vegetative and reproductive features are provided.

Results - Molecular results show that the genetic distances between and within Ixora margaretae dry and humid stands vary similarly. Accordingly, humid stands are interpreted as a part of the broad newly delimited I. margaretae, occurring in fragmented habitats. Morpho-anatomical data show that several features, such as the bark types, the individual height, and the fruit fleshiness result from genetic variability expressed under environmental constraints. However, other features are interpreted as acclimatisation of populations to local conditions, such as the convergent erected receptaculum pollinis for dry and humid stands, obtain by two different anatomical processes. All data suggest that I. margaretae is a species showing genetic isolation and relative adaptations to environments of populations in both humid and sclerophyll forests. This illustrates potential ongoing speciation processes for several populations in both forest types. A scenario showing the successive habitat modifications from humid to sclerophyll forests that can explain the persistence of the species in sclerophyll areas is proposed.
\end{abstract}

Key words - Adaptation, ecology, floral anatomy, genetics, Ixora, forest, morphology, New Caledonia, Rubiaceae.

\section{INTRODUCTION}

The family Rubiaceae is a highly diversified cosmopolitan group of Angiosperms, comprising from 10,000 (Robbrecht 1988, Mabberley 1997) to 13,200 (Davis et al. 2009) species. Since the advent of molecular phylogenies, the intra-familial classification has been considerably modified. One of the largest genera of the family, Ixora L. was shown to be paraphyletic based on molecular data from the plastid markers $r b c L, r p s 16$, and $\operatorname{trnT} T-F$ and the nuclear marker ETS (Mouly et al. 2009a, 2009b). Accordingly, the authors newly defined the generic limits within Ixoreae to accept a single broad
Ixora, including Captaincookia N.Hallé, Doricera Verdc., Myonima Comm. ex A.Juss. and Versteegia Valeton (Mouly et al. 2009b). The genus Ixora sensu Mouly et al. (2009b) is characterised by leaves possessing an articulated petiole, terminal inflorescences, bud aestivation contorted to the left, and ovaries with a single peltately attached ovule per locule. The group is also characterized by "ixoroid pollen presentation" (Nilsson et al. 1990, Puff et al. 1996, De Block 1998, Lorence et al. 2007), consisting of a case of secondary pollen presentation. Insects, predominantly moths, hawkmoths, and butterflies, pollinate Ixora flowers (De Block 1998). 
Ixora margaretae (N.Hallé) Mouly \& B.Bremer was previously placed in Captaincookia (maintained as a current vernacular name in New Caledonia: 'Captaincookia'). This species was considered to be restricted to the threatened sclerophyll forest (Bouchet et al. 1995, Jaffré et al. 1997). The plant bears spectacular flowering with showy red corollas along the defoliated trunk. For these reasons, the plant became one of the flagships for conservation of sclerophyll forest and is nowadays classified as Vulnerable on the IUCN Red List (Hequet 2010). According to Hallé (1973), I. margaretae differs from all other Ixora species by inter alia the following features: drooping flowers and infundibuliform corollas; apiculate and angulose endocarp; umbilicus of the endocarp with an orbicular annulus; floral disk not prominent but fleshy in depth. To these characteristics can be added the staminal filament basally attached to one side of the corolla lobe, the long-exserted style, and the permanently erect stigmatic lobes (Mouly 2007). Ixora margaretae bears caulinary inflorescences, which are solitary flowers clustered at the axil of leaf scars. The floral traits that distinguish Ixora margaretae within the genus Ixora, and notably from the other cauliflorous species, are probably related to an adaptation to different pollinators. Hallé (1973) attributed the flower type of I. margaretae (drooping, reddish/pinkish corolla, with an infundibuliform to campanulate tube) to an adaptation to bird pollination.

Since its discovery in 1973, several stands of Ixora margaretae were found in sclerophyll forests in the Pindai, Tiéa, and Nékoro vicinities (fig. 1). Each population comprises a limited number of individuals. Very recently, three large stands of an Ixora, consisting of several hundreds of individuals each, were found in humid forest of the Western Coast of New Caledonia. These new stands much resemble I. margaretae and share every diagnostic feature cited in the previous paragraph. Considering the high level of specific adaptations to sclerophyll habitats and the level of microendemism in New Caledonia (Grandcolas et al. 2008), the oc-

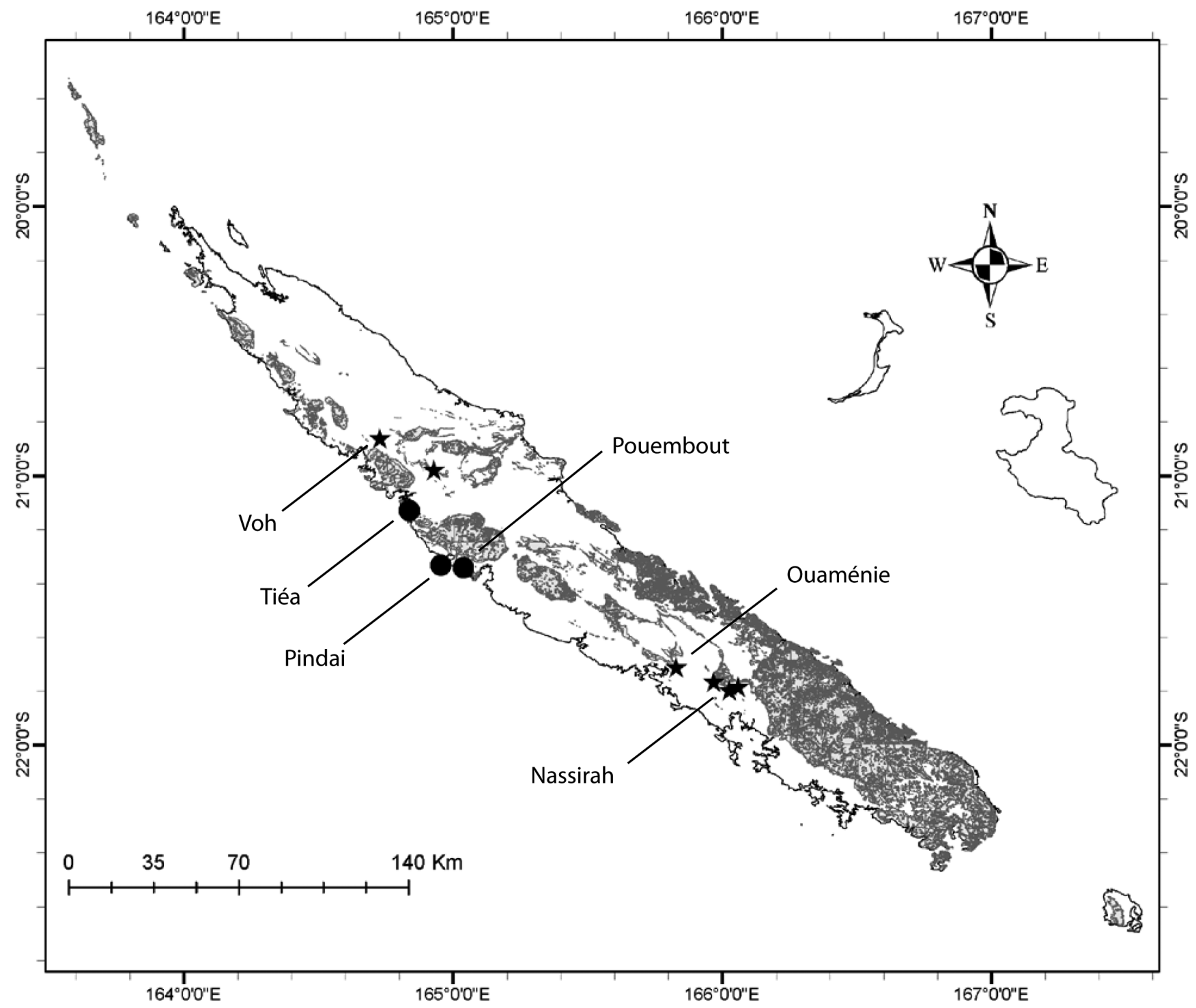

Figure 1 - Distribution map of Ixora margaretae in New Caledonia: sclerophyll $(\bullet)$ and humid forest $(\star)$. 
currence of the species in understory humid forest appears very intriguing.

Two individuals of the newly discovered humid forest stands were included in Mouly et al.'s (2009b) phylogenetic study. They were positioned together with Ixora margaretae in a supported clade sister to a large group of other Pacific Ixora. The lack of resolution within the 'Captaincookia' clade (Mouly et al. 2009b) constitutes evidence for a very close relationship between tested specimens, and the difficulty to distinguish them genetically. Recently, a population genetic study of Ixora margaretae individuals from sclerophyll forest was undertaken (Verhaegen et al. 2013). A few individuals from two of the three known humid forest stands were also included in this study, but they were considered as problematic individuals too distantly related to I. margaretae from the sclerophyll forest.

A careful examination of the morphology of specimens from every location brought to attention some divergent traits between humid forest individuals and sclerophyll forest ones that are detailed in the present study. Here, we investigate the morphology and anatomy of the 'Captaincookia' complex from both sclerophyll and humid forests in New Caledonia. We study the genetic structure of populations to test the taxon limits for the two forest types and attempt possible interpretations of morpho-anatomical divergences in the light of environmental parameters.

\section{MATERIALS AND METHODS}

\section{Population genetics}

Population sampling of the different populations for molecular analysis - Fourteen trees of Ixora margaretae from five distinct areas were sampled, including two of the three humid and the three main sclerophyll stands. Young leaves were collected from trees and dried using silica gel.

SSR genotyping and polymorphism revelation - DNA extraction, PCR conditions and electrophoresis conditions were described in another paper (Verhaegen et al. 2013). Automated infrared fluorescence DNA sequencing was used to find the allele variability according to Steffens et al. (1993). Ten microsatellite loci were amplified using a PCR method. This sequence is complementary to an IR-labelled universal M13 forward sequencing primer, which is included in the PCR mix. During PCR, the tailed primer generates a complementary sequence which is subsequently utilized for priming in the amplification reaction thereby generating IR-labelled PCR products. The samples were electrophoresed on an IR DNA analyzer (LI-COR, Inc) which detects primer-labelled extension products at two different wavelengths (IRDye 700 $\mathrm{nm}$ and IRDye $800 \mathrm{~nm}$ ). This allowed loading of a multiplex of four PCR products in one well. The individual trees were genotyped using SagaGT software (LI-COR, Inc).

Molecular genetic data analysis - The individual distance tree was constructed using Darwin 5.0.148 software (Perrier \& Jacquemoud-Collet 2006), with the neighbour-joining method of Saitou \& Nei (1987). The robustness of each node was evaluated by bootstrapping data over loci for 1,000 replications. Pairwise genetic distances between pairs of provenances were computed with the Cavalli-Sforza chord measure options (Cavalli-Sforza \& Edwards 1967) of the Microsatellite Analyzer (Dieringer \& Schlötterer 2003).

\section{Morphology and anatomy}

Field studies have been undertaken to collect complementary specimens and data. All measurements given are taken from dried herbarium specimens, although some features such as shapes were supplemented with information from alcoholpreserved flowers and fruits, field notes, and colour slides or digital photos. Measurements are presented in the descriptions as follows: length $\times$ width, followed by units of measurement $(\mathrm{mm}$ or $\mathrm{cm})$. Specimens from the following herbaria were studied: L, NOU and P (abbreviations following Thiers continuously updated).

For examination of flower structures, tissues from herbarium material or pickled material were cleared using an aqueous solution of Sodium hydroxide. Upper style halves and stigmas of representative individuals, humid forest Ixora margaretae (Munzinger et al. 3493, P) and sclerophyll forest Ixora margaretae (Mouly et al. 863, P), were restored by $\mathrm{NH}_{4} \mathrm{OH} 50 \%$ at $60^{\circ} \mathrm{C}$, then postfixed by FAA, and processed according to the standard method (Gerlach 1984) i.e., dehydrated by t-butylic alcohol, embedded in paraffin $\left(58-60^{\circ} \mathrm{C}\right)$, sectioned at $10-15 \mu \mathrm{m}$ thickness, stained by an aqueous Astrablue $0.5 \%$ and Ziehl's Fuchsine $10 \%$ (instead of Safranine) combination, then mounted in Eukitt. Slides are kept in the plant slide library of the Herbarium at the National Museum of Natural History, Paris (P), under the numbers "Deroin 194 a \& b (Munzinger et al. 3493, P)"; "Deroin 204 (Mouly et al. 863, P)". We failed to obtain completely mature collections of Ixora margaretae for anatomical investigation so that both stages studied represent early anthesis.

\section{RESULTS}

\section{Genetic distances between Ixora margaretae populations} (fig. 2, table 1)

Microsatellite markers were defined from a tree harvested in the sclerophyll forest of Nekoro (Verhaegen et al. 2013). The SSR locus amplifies all the samples of humid forests without missing data. With the individual genetic distances of Cavalli-Sforza and Edwards, the provenances of Ouaménie, Nassirah and Pouembout separated sharply and the robustness of nodes varied from 50/100 in 97/100 (fig. 2). Genetic distances (GD) between Ixora margaretae stands vary from 0.66 to 0.9 (table 1). The GD observed between the two included humid stands is 0.9 . The minimum GD observed be-

Table 1 - Genetic distance on five stands using DC Cavali-Sforza \& Edwards (1967).

Sclerophyll forest stands: Tiéa, Pouembout, Nékoro; humid forest stands: Nassirah, La Ouaménie.

\begin{tabular}{lllll}
\hline Sites & Nassirah & Nekoro & Tiéa & Pouembout \\
\hline Nekoro & 0,661239 & & & \\
Tiéa & 0,864629 & 0,747837 & & \\
Pouembout & 0,900316 & 0,826577 & 0,698004 & \\
Ouaménie & 0,900316 & 0,8337 & 0,78734 & 0,739217 \\
\hline
\end{tabular}


tween the sclerophyll forest stands is 0.7 and the GD mean was $0.75 \pm 0.06$. The humid forest stand of Ouaménie shows a minimum GD with the dry forest stand of Pouembout (GD $=0.74$ ), while the humid forest stand of Nassirah has a minimum GD to the sclerophyll forest stand of Nékoro (GD = 0.66 ). The GD mean between the slerophyll and humid forests was $0.80 \pm 0.09$.

\section{Morpho-anatomy (figs 3-5, electronic appendix)}

Ixora margaretae individuals from sclerophyll forests differ from those of humid forests by: a shorter height of individuals (1-7m vs. $3-10 \mathrm{~m})$; a thicker bark (suberous vs. non suberous); verticillate phyllotaxy (vs. opposite-decussate); actinomorphic flowers (vs. actinomorphic or slightly zygomorphic); acute corolla bud (vs. rounded). The receptaculum pollinis anatomy of individuals from humid forest, with zygomorphic flowers, differs from those of sclerophyll forests by: asymmetric fusion of stigmatic lobes (vs. symmetric) and asymmetric vascular bundles (vs. symmetric); a persistence of stigmatic lobe erection originating from partial lobe fusion at the apex without specific tissues (vs. non-fused lobes apically with collenchymatous tissues). A detailed morphoanatomy of vegetative and reproductive structures, including the receptaculum pollinis, is available in electronic appendix.

\section{DISCUSSION}

\section{Genetic evidence for an Ixora margaretae population structure without ecological coherence}

Both the humid and sclerophyll forest stands show morphoanatomical specificities that can be interpreted as sufficiently characteristic to diagnose two proximate species adapted to a different environment, or that can suggest a genotypic expression dependent on environment. The genetic structure of stands favours the second hypothesis, as stands do not all form genetic groups, such as Tiéa and Nékoro (fig. 2). Moreover, the individuals from sclerophyll and humid stands do not form distinct clusters. Verhaegen et al. (2013), in a recent work on the sclerophyll forest stands of Ixora margaretae, evaluated the species as comprising geographically isolated, genetically identified populations with low mutual allelic flow. From a morphological point of view Mouly et al. (2009b) previously interpreted specimens from the humid and sclerophyll forest stands as two distinct species. On the other hand, they found no support from molecular phylogenetic reconstruction to group the specimens from humid forest in a separate lineage from the specimens from sclerophyll forest (Mouly et al. 2009b: Figs 2-5). These data all together suggest that Ixora margaretae stands form iso-

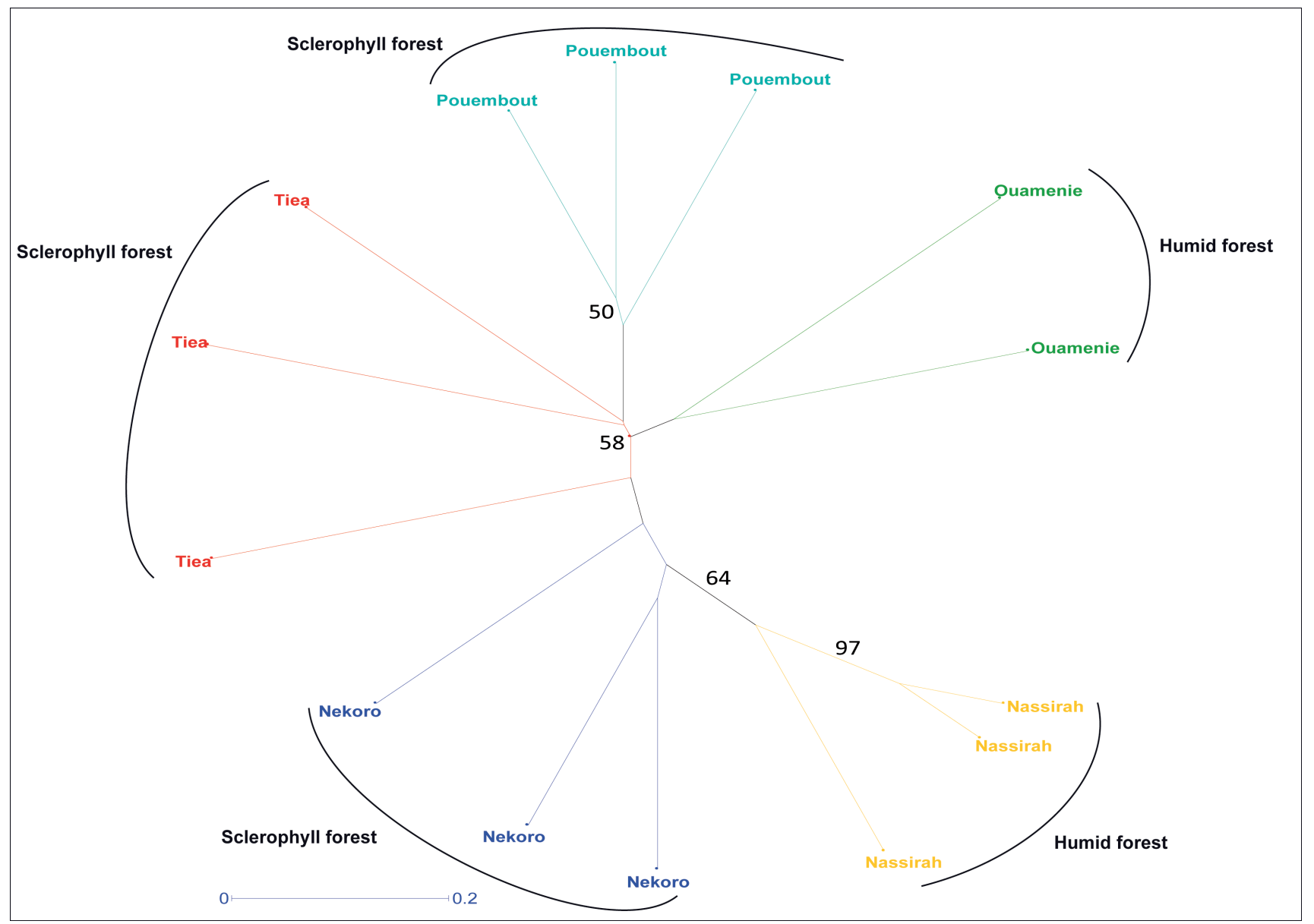

Figure 2 - Neighbour-joining phylogram based on the Cavalli-Sforza \& Edwards (1967) chord method for fourteen individual trees of Ixora margaretae harvested in three sclerophyll and two humid forests of New Caledonia. The robustness of each node was evaluated by bootstrapping data over loci for 1000 replications. 


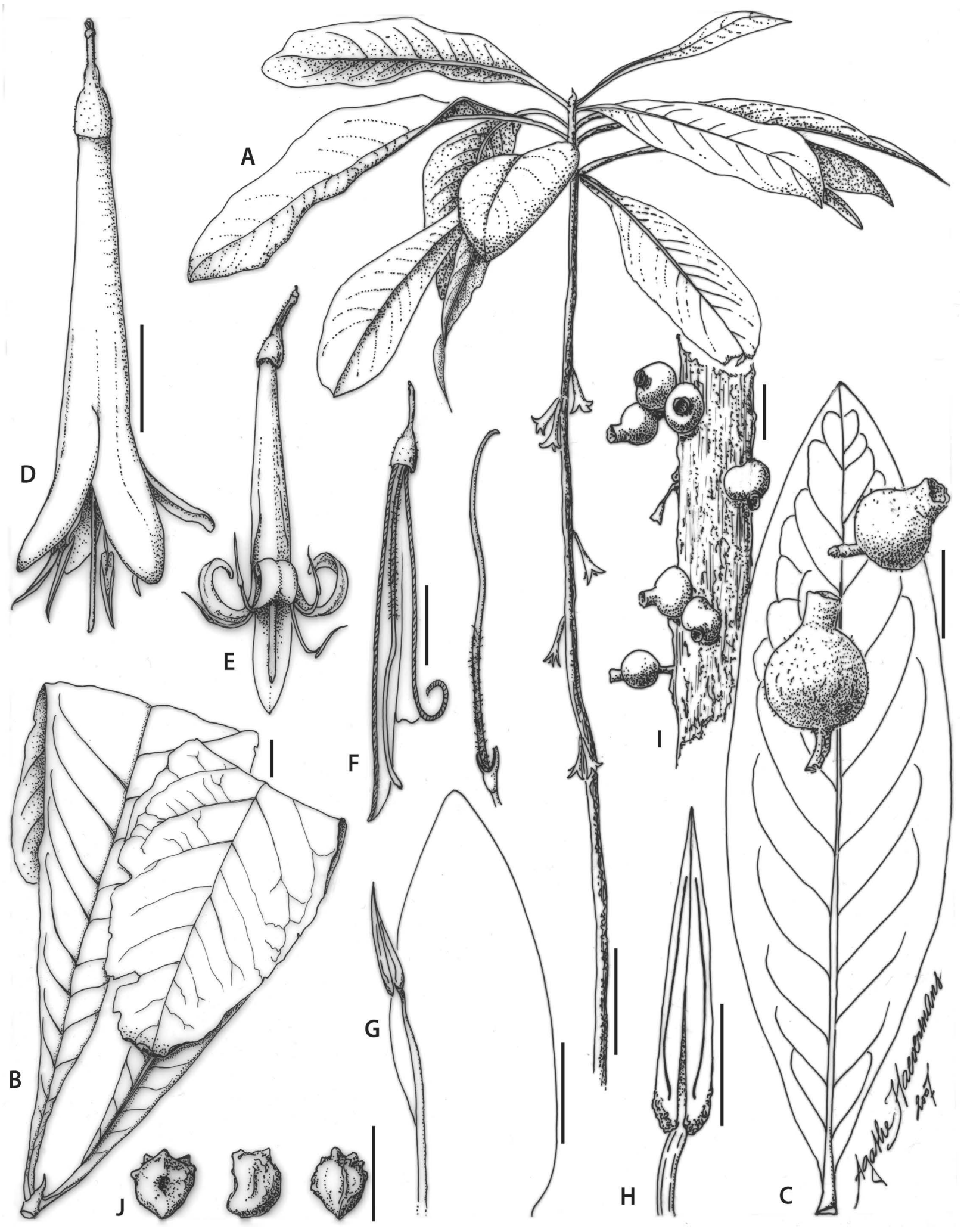

Figure 3 - Illustration of humid forest Ixora margaretae: A, individual bearing flowers; B, terminal leaf pair; C, young individual leaf; D, flower at early anthesis; E, flower at the male stage of anthesis during pollen presentation; $\mathrm{F}$, longitudinal section of the flower in $\mathrm{E}$ showing the bent style; G, placement of the stamen on the corolla lobe; H, ventral view of a stamen before locule dehiscence; I, detail of a trunk bearing fruits, and mature and immature fruits; J, views of pyrene shape (ventral, lateral, and dorsal views from the left). Scale bars: A: 10 cm; B-F, I \& J: 1 cm; G: 8 mm; H: 4 mm. A from picture by Gâteblé; B \& C from Mouly et al. 870 (P); D-J from Munzinger et al. 3493 (P). Drawn by Agathe Haevermans. 

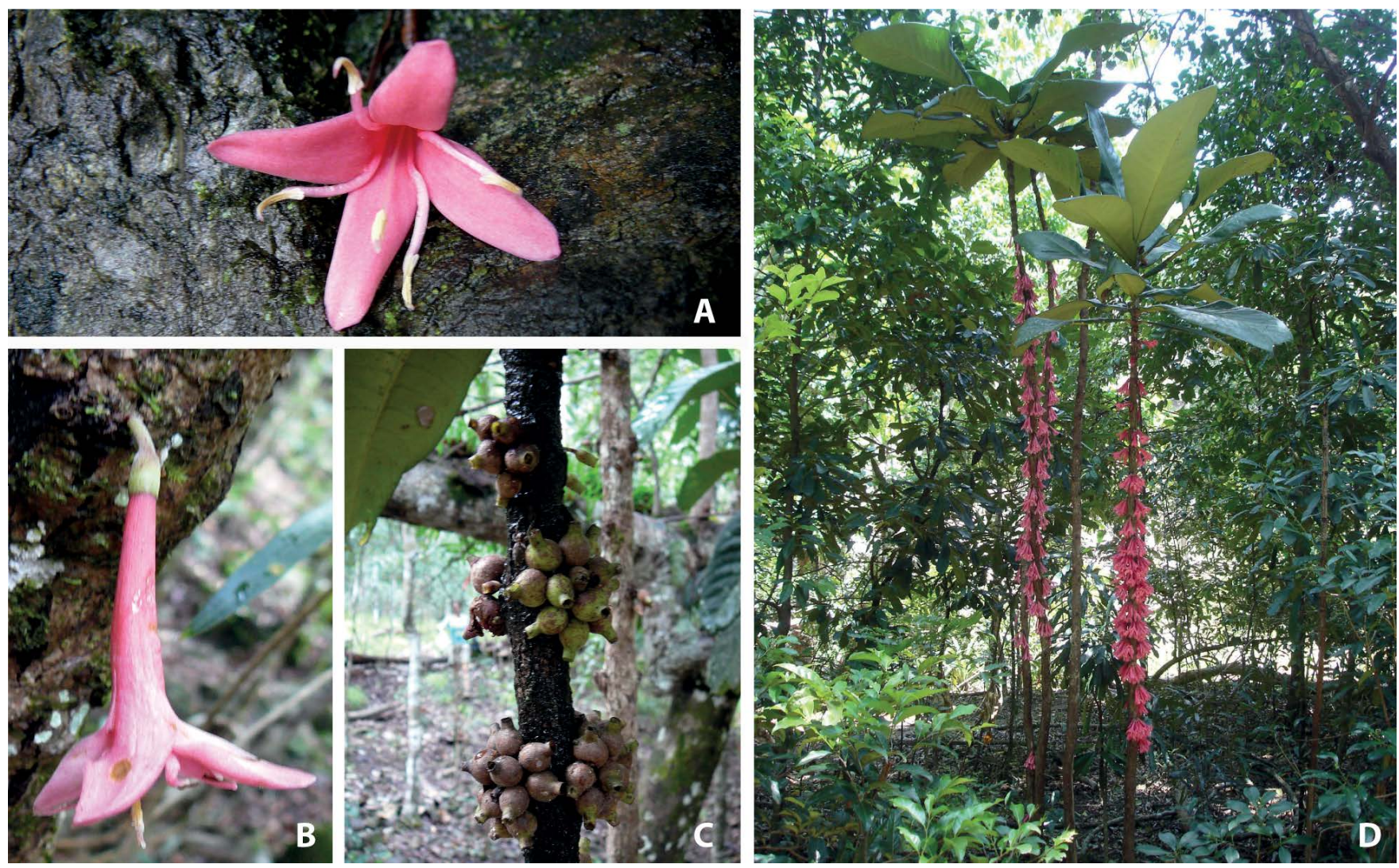

Figure 4 - Morphology of Ixora margaretae in humid forests. A, flower in apical view showing the torsion of the filaments due to its basal fusion to the corolla lobe margin; B, flower in lateral view showing the slightly curved shape of the corolla and the style within it; $\mathrm{C}$, infructescences bearing fleshy fruits; D, flowering individuals with strict monocaulous habit. A, B \& C photographed by A. Mouly; D photographed by Y. Pillon.

lated populations that are not very diverse genetically. The heterozygosity deficit noted by Verhaegen et al. (2013) is due to an apparent limited rate of inter-population genetic exchange amongst the sclerophyll forest stands, seemingly amongst the humid forests stands, and between the sclerophyll and humid stands. In consequence, the ensemble of all stands should be seen as representing a single species with a low genetic diversity and low genetic flows. The low genetic diversity can be explained by the low number of living individuals, especially in sclerophyll forest where some 200 young and mature individuals are known, according to Verhaegen et al. (2013). The higher number of individuals in humid forest stands, probably 2,000 individuals, may result from a recent change in environment of the concerned humid forests (see details below), but no single population exceeds several hundred mature individuals.

\section{Morphological inter-population variability as an answer to environmental factors}

Vegetative structures variability as a response to ecological gradient - The humid forest populations constitute a morphologically coherent group, slightly divergent from the sclerophyll forest $I$. margaretae - being a strictly monocaulous shrub (fig. 4D) vs. monocaulous to pachycaulous and bearing opposite-decussate leaves vs. verticillate (in mature individuals), non suberous cork vs. suberous, pink corollas vs. red corollas, fleshy juicy fruits (fig. 4C) vs. fleshy dry fruits, globose pyrenes vs. hemispherical, among other features.

Some of these variations can easily be explained by infra-specific variability and environmental pressure to phenotypic expression, such as the suberous type of bark in dry environments and thin bark in humid forests. Other stable characters seem less explainable by morphological plasticity under environmental pressure, such as pyrene shape and leaf organisation. On the other hand, another cauliflorous species, I. cauliflora Montrouz., has an even broader range of ecological adaptability, as it grows in sclerophyll, dry, littoral and humid forests. Indeed, I. cauliflora typically has oppositedecussate leaves, but sparse branches can bear verticillate leaves in sclerophyll forest trees (see gathering Mouly 862 in P). Regarding reproductive structures, the pyrene shape was described as very variable by Hallé (1973) for I. cauliflora, and corolla length also depends on ecology (short in sclerophyll forest and long in humid and littoral forests). The considerable variation present within I. cauliflora and its high ecological adaptability support the fact that the different populations of Captaincookia type Ixora individuals are part of a single species with broad ecological and morphological ranges, namely $I$. margaretae.

Inflorescence organization, flower shape, and pollination syndrome - In Ixora, the evolution of pollination is highly 


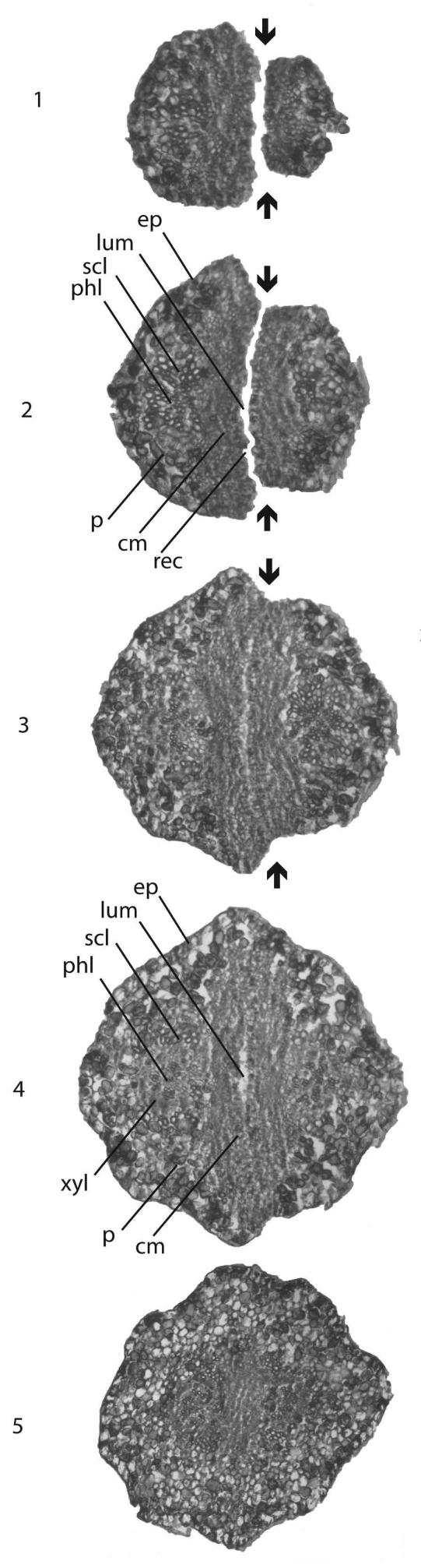

A
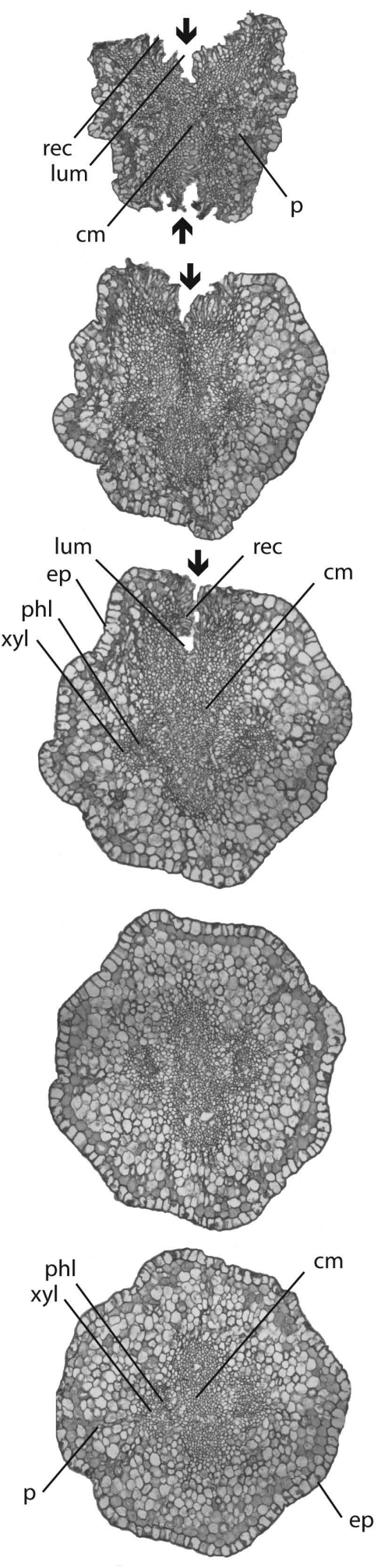

B
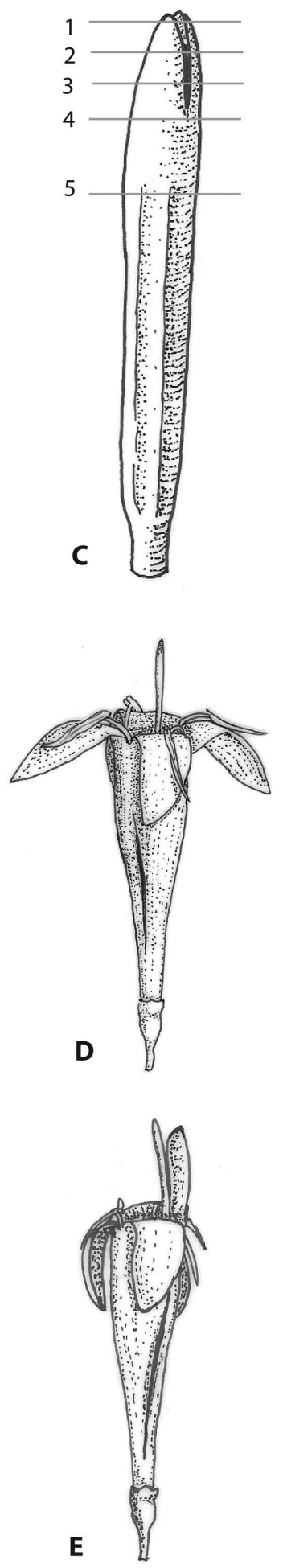

Figure 5 - Transverse serial sections of the receptaculum pollinis in Ixora margaretae. A, actinomorphic flower, sclerophyll forest (Mouly \& Jourdan 863 , P), with erected free stigma lobes $(\times 40)$; B, zygomorphic flower, showing asymmetrical fusion of the stigma lobes and papillae on their margins, humid forest (Munzinger et al. 3493, P) $(\times 40)$; C, drawing of the stigmatic head providing the position of the respective slides for A \& B; D, drawing of a flower from sclerophyll forest (Mouly \& Jourdan 863, P); E, drawing of a zygomorphic flower from humid forest (Munzinger et al. 3493, P). Abbreviations: cm: conductive mass; ep: epidermis; lum: lumen; p: parenchyma; phl: phloem; rec: receptive papillae; scl: sclerenchyma; xyl: xylem; bold arrows: visible places of stigmatic lobe individualization. 
Current distribution of Ixora margaretae in Tiéa

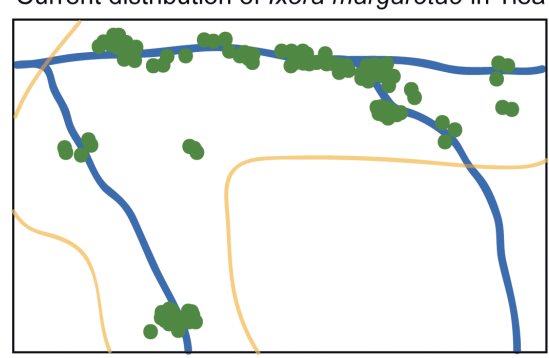

Putative scenario of the environment dynamic explaining Ixora margaretae distribution in Tiéa

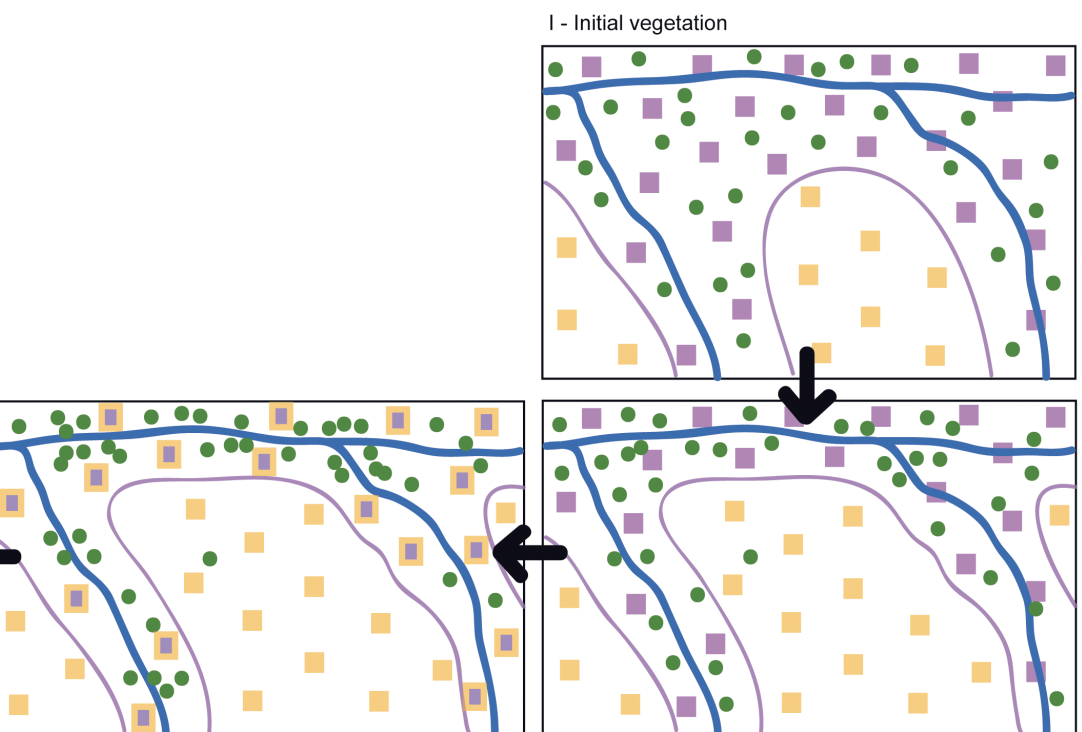

III - Mix of mesic and sclerophyll forests along creeks

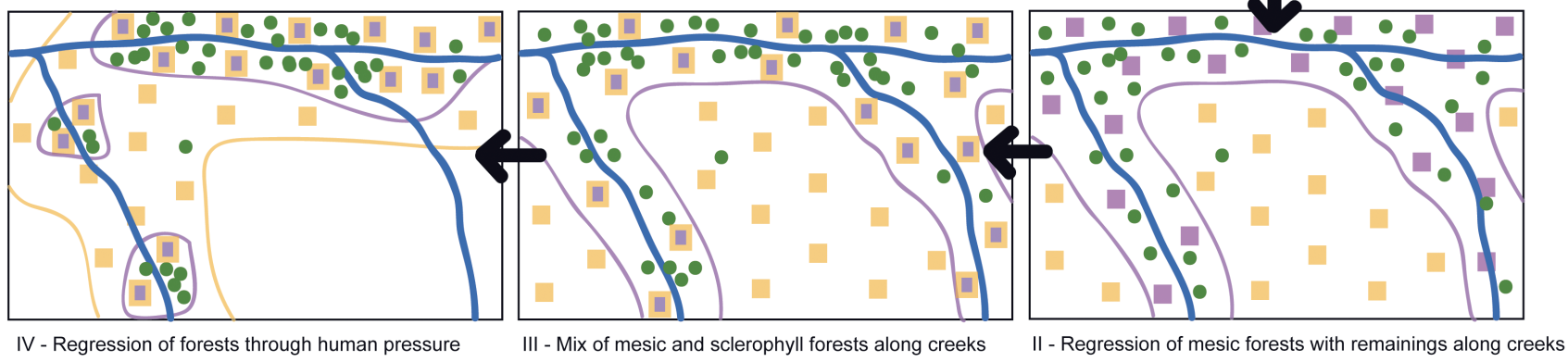

- Individual of Ixora margaretae

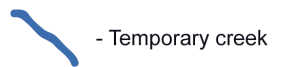

- Sclerophyll forest
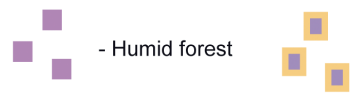

- Mesic forest along creeks

Figure 6 - Current distribution of Ixora margaretae individuals in the sclerophyll forest stand of Tiéa (Verhaegen et al. 2013) and putative scenario of the ecosystems explaining the current mixture of forests.

constrained by the ixoroid pollen presentation mechanism (Nilsson et al. 1990, Puff et al. 1996), meaning the pollen is deposited on the upper part of the style before the flower bud opens. At anthesis, the pollen mass is raised above the corolla tube and is made available for dispersal by the pollen presenter, before the stigma lobes spread and become receptive (Robbrecht 1988, Smith \& Darwin 1988, Lorence et al. 2007). The external wall of the sub-stigmatic mantle is often deeply wrinkled to ensure a better adhesion of the pollen mass, and sometimes stamens excise after pollen deposition. The external layer of large cells, observed on stigma-sections (fig. 5) of each specimen studied, and also present in the African I. brachypoda DC. and I. burundiensis Bridson (De Block 1998), may participate in the adhesion of pollen masses. Hallé (1973) stressed that this type of pollen presentation was unlikely in I. margaretae due to the large and trumpetlike corolla-shape. According to our data and observations, the mechanism of secondary pollen display is always present. Compared to most Ixora species, I. margaretae bears long-exserted styles, a singular feature that can result from the reduction of petal fusion at the throat. This could also explain the partial fusion of the stamen filaments to the lobes (fig. 4A), and/or the important length of the style compared to most other Ixora species.

Another characteristic feature of Ixora margaretae discussed by Mouly et al. (2009b) is the permanently erect short stigmatic lobes, in opposition to long lobes that recurve at late anthesis in other Ixora species. However, the present study demonstrates that this uncommon character state in Ixora is not analogous depending on environments. As observed in the stigma sections (fig. 5), the permanent erection of stigmatic lobes in the sclerophyll forest I. margaretae is mechanically ensured by the development of sclerenchymatous arcs (consisting of two edges apically fused per lobe). In such case, the two stigmatic lobes are independent from each other (fig. 5A). In the humid forest I. margaretae, the erection of the lobes is ensured by the partial fusion of the stigmatic lobes in their centre (fig. 5B). The vascularisation suggests the presence of two lobes terminating the stigma, in regards to the two conducting bundles differentiated in the stigmatic head. On the other hand, we found no evidence of sclerenchymatous tissues that reinforce the stigmatic head in this group.

The floral organisation is somewhat variable within humid forest populations. There, flowers sometimes bear a style bent in its middle and arched in the upper half (fig. 5E), the stigmatic head not being located in the flower centre (fig. 4B), but shifted toward one side of the corolla. Rubiaceae in bud stage often have a style in ' $\mathrm{S}$ ' shape that erects itself at anthesis (cf. Mouly 2006: Fig. 1B, in Psydrax paradoxa (Virot) Mouly), which would easily explain the observed feature here. However, there is no record of this phenomenon in Ixora in general, and our careful observations of I. margaretae bud stages never revealed such a "S" shaped early style, but a style constantly erect from early buds to mature buds. Moreover, as a consequence of the modification of the gynoecium, the stigmatic head appears asymmetrical and its stigmatic lobes are conspicuously fused (fig. 5B). In this configuration a long papillose margin (c. $3 \mathrm{~mm}$ ) runs along the stigmatic side presented to pollinator, while a shorter one (c. $1 \mathrm{~mm}$ ) is present on the side faced to the plant trunk. These morphological, anatomical, and mechanical features 
result in a slightly zygomorphic flower, in the sense of Robertson (1888), the flower having just one plane of symmetry (Neal et al. 1998).

The variability of reproductive features listed above for Ixora margaretae may result from pollination syndromes (Kato \& Kawakita 2004). Sclerophyll forest individuals of Ixora margaretae are often suggested to be adapted to pollination by birds, notably Melliphagidae, considering the shape and colour of the corolla (Hallé 1973, Faegri \& van der Pijl 1979, Kato \& Kawakita 2004). Bird-pollination was also described for other New Caledonian Rubiaceae with campanulate or trumpet-like corollas, often vividly coloured, as Thiollierea Montrouz (Barrabé et al. 2011). In the humid forest Ixora margaretae flowers with long-exserted and somewhat arched style, the pollen mass might potentially be deposited on the pollinator at a different location than in other Ixora species (not verified in nature). The observed variability in the level of zygomorphy of flowers and the length of styles in humid forest I. margaretae can represent a heterotypic expression (Rudall \& Bateman 2002), resulting from an ongoing adaptation of the pollen presentation to new pollinators and/or to various pollinators. Evolution to zygomorphy is often linked to bat pollination (Kato \& Kawakita 2004). Several bat species occur in New Caledonia (Sanborn \& Nicholson 1950) of which several ones evolve in humid forests.

\section{To a speciation process engendered by a regression of humid forests on the West coast and introduced herbivorous influence?}

Species concept and indication of speciation process in Ixora margaretae - In the light of the genetic distance tree information (fig. 2), most of the character variation found between specimens from sclerophyll and humid stands are here interpreted as genetic variation driven by environmental forces within a single species,. On the other hand, the apparent lack of sufficient genetic exchanges between stands and the reduced numbers of individuals per stand in sclerophyll environments induces genetic isolation and subsequent loss of heterozygosity within stands (Verhaegen et al. 2013). The low number of individuals per stand may favour genetic drift. If the stands are able to survive the loss of heterozygosity, in a stable environment, they may be subject to a pre- or post-zygotic barrier with other stands. For instance, Verhaegen et al. (2013) noted that the stands from Nékoro and Tiéa present different but still partially overlapping blooming and fruiting periods. The genetic, morphological and geographical patterns in the species Ixora margaretae seem to indicate an ongoing speciation process due to the fragmentation of habitat and genetic isolation.

Negative selection in sclerophyll forest stands vs. positive selection in humid forest stands: a conservation nightmare - Humid forest stands appear rich in individuals compared to sclerophyll forest stands. The populations in sclerophyll forests are endangered by human activities, e.g. farming and volunteer fires. Moreover, Verhaegen et al. (2013) observed a high proportion of fruit predation by introduced rats. The populations in humid forests are larger and Ixora margaretae may locally be the most common under- story shrub, together with other Rubiaceae such as Psychotria semperflorens Pancher ex Beauvis. and Gardenia aubryi Vieill. The understory of the humid forests is quite empty due to predation of the introduced Rusa dear, a high threat to New Caledonian' biodiversity (De Garine-Wichatitsky et al. 2005). The very thick, large, and fibrous leaves, apically disposed on the top of a single erected trunk, seem to reduce the risk of consumption of I. margaretae by the introduced dear. In these conditions, Ixora margaretae is presently negatively selected by both human activities and predation in sclerophyll forest stands, while it is positively selected in humid forest stands by predation of other species inducing reduced competition. On the other hand, both types of populations evolve in highly perturbed environments, and even though the stands in humid forests seem to progress nowadays, they are still threatened and should also be considered for protection.

History of Ixora margaretae and its environment - Interestingly, the mapping of Ixora margaretae in Tiéa by Verhaegen et al. (2013) shows that individuals are mainly located along the temporary creeks (redrawn in fig. 6), and their vegetation analysis reveals a mixture of typical sclerophyll forest plants and humid or euryecious forest plants such as Diospyros yaouhensis (Schltr.) Kosterm., Jasminum didymium G.Forst., Ixora cauliflora, and Codiaeum peltatum (Labill.) P.S.Green. Jaffré et al. (2008) mentioned peculiar plant communities in the most humid parts of sclerophyll forests, of which Ixora margaretae is a member. The observed pattern of distribution with euryecious species in moist environments of sclerophyll forests illustrates the presence of transitions between the sclerophyll and humid forest. According to this, Jaffré et al. (2008) suggested that "mesic forest" lacks from the currently recognized vegetation types in New Caledonia, and would need to be studied in detail. The presence of large leaves in Ixora margaretae is contradictory with sclerophylly, and the distribution of the species in both sclerophyll and humid forests may represent complementary evidence to recognize mesic forests in New Caledonia. The presence of Ixora margaretae stands in proximate humid forest areas suggests that populations observed in sclerophyll forests should be seen as relicts from a regression of mesic forests along the West coast of New Caledonia (cf. putative scenario presented in fig. 6). Consequently, the vegetation found along temporary creeks in sclerophyll forest should consist of an intermediate stage between progressing sclerophyll and regressing humid forest, with a typical vegetation comprising elements of both types that forms mesic forests. However, the sclerophyll forest is currently not progressing anymore, and even intensively regressing forming relict patches due to human activities, among which deforestation to open pasture lands (Bouchet et al. 1995). It is difficult to know whether the tipping point marking the beginning of the mesic forest regression is natural and old, or, as for sclerophyll forests, recently forced by human activities.

\section{SUPPLEMENTARY DATA}

Supplementary data are available in pdf at Plant Ecology and Evolution, Supplementary Data Site (http://www.ingentaconnect.com/content/botbel/plecevo/supp-data), and consist of 
a complete description of morpho-anatomical features for Ixora margaretae stands in sclerophyll and humid forests.

\section{ACKNOWLEDGMENTS}

We wish to thank the Northern and Southern Provinces of New Caledonia Territory for allowing the collection of specimens; Joël Jérémie (Muséum national d'Histoire naturelle, Paris), and Jacques Florence (Institut de Recherche pour le Développement, Paris) for their useful comments on the manuscript; Jean-Marie Veillon and Tanguy Jaffré for their help and advice; Gildas Gâteblé (Institut Agronomique néoCalédonien,) for data about population localities and pictures; Irène \& Daniel Létocart, and Jean-Pierre Butin for precious information about populations and seed germination, plant pictures, as well as help during fieldwork; Agathe Haevermans for illustrations of Ixora margaretae in figs 4 \& 5; Directors and teams of visited herbaria: BR, G, L, NOU, P, and PAP, plus $\mathrm{K}$ and MO for providing loans. Financial support was provided by the UMS CNRS 2700 - USM MNHN 0602 "Taxonomie et Collections", the Department "Systématique et Evolution", Muséum National d'Histoire Naturelle, Paris and the European Union (EU) through the Synthesys program to A. Mouly for visiting BR and L herbaria.

\section{REFERENCES}

Barrabé L., Mouly A., Lowry II P.P., Munzinger J. (2011) Reinstatement of the endemic New Caledonian genus Thiollierea Montrouz. (Rubiaceae) necessitated by the polyphyly of Bikkia Reinw. as currently circumscribed. Adansonia sér. 3, 33: 115134. http://dx.doi.org/10.5252/a2011n1a8

Bouchet P., Jaffré T., Veillon J.-M. (1995) Plant extinction in New Caledonia: protection of sclerophyll forests urgently needed. Biodiversity \& Conservation 4: 415-428. http://dx.doi. org/10.1007/BF00058425

Cavalli-Sforza L.L., Edwards A.W.F. (1967) Phylogenetic analysis: models and estimation procedures. Evolution 32: 550-570. http://dx.doi.org/10.2307/2406616

Davis A.P., Govaerts R., Bridson D.M., Ruhsam M., Moat J., Brummit N.A. (2009) A global assessment of distribution, diversity, endemism, and taxonomic effort in the Rubiaceae. Annals of the Missouri Botanical Garden 96: 68-78. http://dx.doi. org/10.3417/2006205

De Block P. (1998) The African species of Ixora (Rubiaceae Pavetteae). Opera Botanica Belgica 9: 1-218.

De Garine-Wichatitsky M., Soubeyran Y., Maillard D., Duncan P. (2005) The diets of introduced rusa deer (Cervus timorensis russa) in a native sclerophyll forest and a native rainforest of New Caledonia. New Zealand Journal of Zoology 32: 117-126.

Dieringer D., Schlötterer C. (2003) MICROSATELLITE ANALYSER (MSA): a platform independent analysis tool for large microsatellite data sets. Molecular Ecology Notes 3: 167-169. http://dx.doi.org/10.1046/j.1471-8286.2003.00351.x

Faegri K., van der Pijl L. (1979) The principles of pollination ecology. $3^{\text {rd }}$ Ed. Oxford, Pergamon Press.

Grandcolas P., Murienne J., Robillard T., Desutter-Grandcolas L., Jourdan H., Guilbert, E., Deharveng L. (2008) New Caledonia: a very old Darwinian island? Philosophical Transactions of the Royal Society of London - Series B : Biological Sciences 363: 3309-3317. http://dx.doi.org/10.1098/rstb.2008.0122
Gerlach D. (1984) Botanische Mikrotechnik. $3^{\text {rd }}$ Ed. Stuttgart, Thieme.

Hallé N. (1973) Captaincookia, genre nouveau monotypique néocalédonien de Rubiaceae - Ixoreae. Adansonia, sér. 2, 13: 195202.

Hequet V. (2010) Ixora margaretae. In: IUCN Red List of Threatened Species. Version 2013.2. Available at http://www.iucnredlist.org [accessed 10 Feb. 2014].

Jaffré T., Bouchet P., Veillon J.M. (1997) Threatened plants of New Caledonia: is the system of protected areas adequate? Biodiversity \& Conservation 7: 109-135. http://dx.doi. org/10.1023/A:1008815930865

Jaffré T., Rigault F., Munzinger J. (2008) Identification and characterization of floristic groups in dry forests relicts of a West Coast region of New Caledonia. Pacific Conservation Biology 14: $128-145$.

Kato M., Kawakita A. (2004) Plant-pollinator interactions in New Caledonia influenced by honey bees. American Journal of Botany 91: 1814-1827. http://dx.doi.org/10.3732/ajb.91.11.1814

Lorence D.H., Wagner W.L., Mouly A., Florence J. (2007) Revision of Ixora (Rubiaceae) in the Marquesas Islands (French Polynesia). Botanical Journal of the Linnean Society 155: 581-597. http://dx.doi.org/10.1111/j.1095-8339.2007.00732.x

Mabberley D.J. (1997) The plant book. A portable dictionary of the higher plants. $2^{\text {nd }} E d$. Cambridge, The Press syndicate of the University of Cambridge.

Mouly A. (2006) Statut de Plectronia paradoxa Virot, Rubiaceae myrmécophile de Nouvelle-Calédonie. Adansonia, sér. 3, 28: 161-166.

Mouly A. (2007) Systématique de la tribu des Ixoreae A.Gray (Rubiaceae): phylogénie, biogéographie et taxonomie. PhD Thesis, Muséum National d'Histoire Naturelle, Paris, France.

Mouly A., Razafimandimbison S.G., Florence J., Jérémie J., Bremer B. (2009a) Paraphyly of Ixora and new tribal delimitation of Ixoreae (Rubiaceae): inference from combined chloroplast (rps16, rbcL and trnT-F) sequence data. Annals of the Missouri Botanical Garden 96: 146-160. http://dx.doi. org/10.3417/2006194

Mouly A., Razafimandimbison S.G., Khodabandeh A., Bremer B. (2009b) Phylogeny and classification of the giant pantropical showy genus Ixora (Rubiaceae-Ixoreae) with indications of geographical monophyletic units and hybrids. American Journal of Botany 96: 686-706. http://dx.doi.org/10.3732/ajb.0800235

Neal P.R., Dafni A., Giurfa M. (1998) Floral symmetry and its role in plant-pollinator systems: terminology, distribution, and hypotheses. Annual Review of Ecology, Evolution, and Systematics 29: 345-373. http://dx.doi.org/10.1146/annurev.ecolsys.29.1.345

Nilsson L.A., Rabakonandrianina E., Pettersson B., Ranaivo J. (1990) "Ixoroid" secondary pollen presentation and pollination by small moths in the Malagasy treelet Ixora platythyrsa (Rubiaceae). Plant Systematics and Evolution 170: 161-165. http:// dx.doi.org/10.1007/BF00937701

Perrier X., Jacquemoud-Collet J.P. (2006) DARwin software. Cirad-Bios UPR Genetic Improvement of Vegetatively Propagated Crops, distributed by the authors. Available at http://darwin.cirad.fr/darwin [accessed 2 Jan. 2016].

Puff C., Robbrecht E., Buchner R., De Block P. (1996) A survey of secondary pollen presentation in the Rubiaceae. Opera Botanica Belgica 7: 369-402.

Robertson C. (1888) Zygomorphy and its causes. III. Botanical Gazette 13: 224-230. 
Robbrecht E. (1988) Tropical woody Rubiaceae: characteristic features and progressions. Contributions to a new subfamilial classification. Opera Botanica Belgica 1: 1-271.

Rudall P., Bateman R.M. (2002) Roles of synorganisation, zygomorphy and heterotopy in floral evolution: the gynostemium and labellum of orchids and other lilioid monocots. Biological Reviews 77: 403-441. http://dx.doi.org/10.1017/ S1464793102005936

Saitou N., Nei M. (1987) The neighbor-joining method: a new method for reconstructing phylogenetic trees. Molecular Biology Evolution 4: 406-425.

Sandborn C.C., Nicholson A.J. (1950) Bats from New Caledonia, the Solomon Islands, and New Hebrides. Fieldiana, Zoology 31: 313-338. http://dx.doi.org/10.5962/bhl.title.3838

Smith A.C., Darwin S.P. (1988) Family 168. Rubiaceae. In: Smith A.C., Darwin S.P. (eds) Flora Vitiensis Nova, vol. 4: 143-362. Hawaii, NTBG Press.

Steffens D.L., Sutter S.L., Roemer S.C. (1993) An alternate universal forward primer for improved automated DNA sequencing of M13. BioTechniques 15: 580-582.

Thiers B. (continuously updated) Index Herbariorum: a global directory of public herbaria and associated staff. New York Bo- tanical Garden's Virtual Herbarium. Available at http://sweetgum.nybg.org/science/ih/ [accessed 18 Nov. 2015].

Verhaegen D., Assoumane A., Serret J., Noe S., Favreau B., Vaillant A., Gâteblé G., Pain A., Papineau C., Maggia L., Tassin J., Bouvet J.M. (2013) Structure and genetic diversity of Ixora margaretae an endangered species. A baseline study for conservation and restoration of natural dry forest of New Caledonia. Tree Genetics \& Genomes 9: 511-524. http://dx.doi.org/10.1007/ s11295-012-0575-7

Manuscript received 16 Jul. 2014; accepted in revised version 28 Sep. 2015.

Communicating Editor: Elmar Robbrecht. 